\title{
28-Homobrassinolide alleviates oxidative stress in salt- treated maize (Zea mays L.) plants
}

\author{
Nitika Arora, Renu Bhardwaj*, Priyanka Sharma and Hardesh K. Arora
}

Department of Botanical \& Environmental Sciences, Guru Nanak Dev University, Amritsar 143005 (Punjab), India. *Corresponding author: renubhardwaj82@gmail.com

Received: 03 May 2008; Returned for revision: 18 June 2008; Accepted: 30 June 2008

The present investigation was undertaken to study the effects of 28-homobrassinolide on the activities of antioxidative enzymes such as superoxide dismutase (EC 1.15.1.1), guaiacol peroxidase (EC 1.11.1.7), catalase (EC 1.11.1.6), glutathione reductase (EC 1.6.4.2) and ascorbate peroxidase (EC 1.11.1.11), as well as protein and malondialdehyde concentrations in 30d-old plants of Zea mays L. grown under salt stress. The seeds were soaked in 28 -homobrassinolide solutions $\left(0,10^{-8}, 10^{-6}\right.$ and $10^{-4} \mathrm{mM}$ ) for $12 \mathrm{~h}$ and then sown in the field in a randomized block layout. The blocks were salinised with $\mathrm{NaCl}$ at concentrations of $0,25,50$ and $75 \mathrm{mM}$. The activities of antioxidative enzymes and protein concentration increased in 28homobrassinolide-treated plants. Despite the enhancement of enzyme activities under salt stress alone, lipid peroxidation increased and protein concentration decreased. However, pre-sowing treatments of 28-homobrassinolide further enhanced the activities of antioxidative enzymes in addition to lowering lipid peroxidation and increasing protein concentration, thus suggesting that 28-homobrassinolide can alleviate oxidative stress in salt-treated maize plants.

Key words: antioxidative enzymes, brassinosteroids, lipid peroxidation, maize, salt stress

28-Homobrassinolídeo reduz o estresse oxidativo em plantas de milho (Zea mays L.) tratadas com sal: Objetivou-se estudar os efeitos do 28-homobrassinolídeo sobre as atividades de enzimas antioxidantes [dismutase do superóxido (EC 1.15.1.1), peroxidase do guaiacol (EC 1.11.1.7), catalase (EC 1.11.1.6), redutase da glutationa (EC 1.6.4.2) e peroxidase do ascorbato (EC 1.11.1.11)] e concentrações de proteínas e aldeído malônico em plantas de milho com 30 d de idade, cultivadas sob estresse

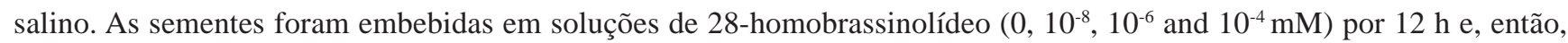
semeadas no campo, seguindo-se um desenho experimental de blocos ao acaso. Os blocos foram salinizados com $\mathrm{NaCl}$ a concentrações de 0, 25, 50 e 75 mM. As atividades das enzimas antioxidantes e a concentração protéica aumentaram nas plantas tratadas com 28-homobrassinolídeo. A despeito do aumento das atividades das enzimas sob estresse salino isoladamente, a peroxidação lipídica aumentou e a concentração protéica reduziu-se. Todavia, tratamentos de pré-emergência com 28-homobrassinolídeo promoveram aumentos adicionais nas atividades das enzimas antioxidantes, além de acarretar decréscimos na peroxidação lipídica e aumentos na concentração protéica, sugerindo, portanto, que o 28-homobrassinolídeo pode aliviar o estresse oxidativo em plantas de milho sob estresse salino

Palavras-chave: brassinosteróides, enzimas antioxidantes, estresse salino, milho, peroxidação lipídica

Salt stress is one of the major abiotic stresses faced by plants, which adversely affect their productivity. Many crop plants such as barley, maize and rice, are often subject to salinity stress (Sairam and Tyagi, 2004). Salinity also leads to oxidative stress in plants due to the production of reactive oxygen species (ROS) such as the superoxide radical, hydrogen peroxide, hydroxyl radical and alkoxyl radical. These ROS produced in the cell are detoxified by both non-enzymatic and enzymatic antioxidant systems. The enzymatic antioxidative system consists of several enzymes such as guaiacol peroxidase (POD), catalase (CAT), superoxide dismutase (SOD), 
ascorbate peroxidase (APX), and glutathione reductase (GR) (Asada and Takahashi, 1987; Arora et al., 2002). A number of plant hormones such as ethylene, abscisic acid, salicylic acid and steroids are involved in the regulation of the plant antioxidative enzymatic system (Cao et al., 2005).

Brassinosteroids (BRs) are hydroxylated derivatives of cholestane, which play an essential role in plant growth and development by influencing various physiological responses (Bajguz and Tretyn, 2003). One of the most important roles of BRs is their ability to confer resistance to plants against various abiotic/biotic stresses such as heat, drought, heavy metals, infection, pesticides, salt and even viruses (Kagale et al., 2007). Under the influence of this group of plant steroids, Özdemir et al. (2004) and Nunez et al. (2003) observed that resistance to stresses involves regulation of antioxidative enzyme activities. However until now, no data have been documented on salt stress management by BRs in maize plants. The objective of the present study was therefore to investigate the influence of 28homobrassinolide (HBL) on activities of antioxidative enzymes, lipid peroxidation and protein content of maize plants under salt $(\mathrm{NaCl})$ stress.

A field experiment was conducted to study the effects of seed-presowing treatment of HBL on biochemical parameters of maize (Zea mays L. var. Partap-1) plants grown under salt stress. Seeds were surface sterilised with $0.05 \%$ mercuric chloride for 5 min followed by repeated rinses in sterile distilled water. Seeds were soaked for $12 \mathrm{~h}$ in aqueous solution of different concentrations of HBL. The stock solution (1 mM) of HBL (Sigma Aldrich, New Delhi, India) was prepared in DMSO and further serial dilutions were made with doubledistilled water to prepare different concentrations of HBL $\left(0,10^{-8}, 10^{-6}\right.$ and $\left.10^{-4} \mathrm{mM}\right)$. The field area was divided into randomised blocks that were salinised with $\mathrm{NaCl}$. For salinisation of each block, soil was removed to a depth of $30 \mathrm{~cm}$. The soil was weighed and salt mixed with this soil to obtain a final concentration of salt in the soil of $0,25,50$ and $75 \mathrm{mM}$. The treated soil was then uniformly distributed in the respective blocks. One salinised block was separated from another by a border of $c a .20 \mathrm{~cm}$ long and $15 \mathrm{~cm}$ in height to avoid cross-contamination by salt between blocks. The field soil consisted of clay, sand and manure in the ratio of 2:1:1, respectively. The plants were grown under field conditions during the normal cropgrowing season (June-August) with a supplementary water supply (sprinkler irrigation). After $30 \mathrm{~d}$ from sowing, leaves of the maize plants were harvested from the second whorl from the top for the study of various biochemical parameters.

For biochemical assays, $1 \mathrm{~g}$ of shoot tissue was homogenized in $3 \mathrm{~mL}$ of $100 \mathrm{mM}$ potassium phosphate buffer ( $\mathrm{pH} 7.0)$. The homogenate was centrifuged at $4^{\circ} \mathrm{C}$ for $20 \mathrm{~min}$ at $15,000 \mathrm{~g}$. The supernatant was used for assays of antioxidative enzymes and protein concentration. Each treatment consisted of three replicates. The activity of SOD was determined by monitoring its ability to inhibit photochemical reduction of nitrobluetetrazolium at $540 \mathrm{~nm}$ (Kono, 1978), and CAT activity was determined by following the initial rate of disappearance of $\mathrm{H}_{2} \mathrm{O}_{2}$ at $240 \mathrm{~nm}$ (Aebi, 1974). The activities of POD, APX and GR were measured according to Putter (1974), Nakano and Asada (1981) and Carlberg and Mannervik (1975), respectively. Protein concentration was determined following the method of Lowry et al. (1951). Lipid peroxidation was determined as the concentration of malondialdehyde (MDA) in a shoot extract prepared in $0.1 \%$ trichloroacetic acid, using the thiobarbituric acid reaction as described by Heath and Packer (1968). The data were analyzed statistically by using one-way analysis of variance (ANOVA); means were compared by Tukey's HSD (Honestly Significant Differences) test and differences with $P$ values $\leq 0.05$ were considered significant (Bailey, 1995). Data are presented as the mean \pm SE.

The studies conducted on biochemical parameters of salt-stressed maize plants indicated significant effects of HBL treatments (Table 1). Activities of antioxidative enzymes (SOD, POD, CAT, APX and GR) were enhanced in maize plants raised from seeds pre-treated with HBL alone, with the $10^{-6} \mathrm{mM}$ concentration being the most effective since it produced the highest HSD (Honestly Significant Differences) value (Table 1). The activities of these enzymes also increased in response to salt additions with further enhancement in plants pre-treated with HBL and grown in salinised soil (Table 2). Maximum increase in SOD activity (17.47 $\mathrm{U} \mathrm{min}^{-1} \mathrm{mg}^{-1}$ protein) was observed in plants treated with $\mathrm{HBL}$ at $10^{-8} \mathrm{mM}$ and grown under $25 \mathrm{mM} \mathrm{NaCl}$ as compared to untreated plants grown under $25 \mathrm{mM} \mathrm{NaCl}$ only $\left(11.01 \mathrm{U} \mathrm{min}^{-1} \mathrm{mg}^{-1}\right.$ 
protein). The activity of POD was maximum in plants grown under $75 \mathrm{mM} \mathrm{NaCl}$ (12.27 mmol GDHP $\mathrm{min}^{-1} \mathrm{mg}^{-1}$ protein) when compared with the other salt treatments without HBL application. Seed-presowing treatment of HBL to salt-stressed plants further enhanced POD activity that was maximum (13.99 mmol GDHP $\mathrm{min}^{-1} \mathrm{mg}^{-1}$ protein) in plants raised from seeds pre-treated with $\mathrm{HBL}$ at $10^{-8} \mathrm{mM}$ concentration and grown under $25 \mathrm{mM} \mathrm{NaCl}$. Similarly maximum CAT activity in plants treated with salt only was observed at $75 \mathrm{mM} \mathrm{NaCl}\left(9.13 \mathrm{~mol} \mathrm{H}_{2} \mathrm{O}_{2} \mathrm{~min}^{-1} \mathrm{mg}^{-1}\right.$ protein). Maximum enhancement in CAT (11.30 mol $\mathrm{H}_{2} \mathrm{O}_{2}$ $\mathrm{min}^{-1} \mathrm{mg}^{-1}$ protein) and APX (13.95 mmol ascorbate min $^{-1}$ $\mathrm{mg}^{-1}$ protein) activities were found in plants treated with $\mathrm{HBL}$ at $10^{-8} \mathrm{mM}$ and grown under $50 \mathrm{mM}$ of $\mathrm{NaCl}$. Similarly GR activity was maximum (3.71 mmol NADPH min ${ }^{-1} \mathrm{mg}^{-1}$ protein) in plants raised from $10^{-4} \mathrm{mM}$ HBL-pre-treated seeds and grown under $50 \mathrm{mM} \mathrm{NaCl}$ (Tables 1 and 2).

Plants raised from seeds pre-treated with HBL alone showed an increase in soluble protein concentration in comparison with untreated seedlings, $10^{-6} \mathrm{mM}$ of $\mathrm{HBL}$ being the most effective (Table 1). On the other hand, protein concentration decreased with increasing salt concentration (Table 2). Plants treated with HBL at $10^{-6}$ $\mathrm{mM}$ and grown under $25 \mathrm{mM} \mathrm{NaCl}$, led to maximum enhancement in protein concentration (30.78 $\mathrm{g} \mathrm{kg}^{-1} \mathrm{FW}$ ) relative to control plants grown under the same salt concentration (27.30 $\mathrm{g} \mathrm{kg}^{-1} \mathrm{FW}$ ). The concentration of MDA increased in salt-stressed plants. However HBL application decreased the MDA levels, especially in plants treated with $\mathrm{HBL}$ at $10^{-6} \mathrm{mM}$ and grown under 50 $\mathrm{mM} \mathrm{NaCl}$ (4.66 mmol kg-1 $\mathrm{FW}$ ) relative to HBL-untreated plants raised under $50 \mathrm{mM} \mathrm{NaCl}$ (6.74 mmol kg-1 FW) (Tables 1 and 2).
Pre-sowing treatment of HBL significantly improved plant tolerance to saline conditions by enhancing the activities of antioxidative enzymes and protein concentration. Generally, salt stress impairs plant growth by affecting water absorption and other biochemical processes such as increases in activity of antioxidative enzymes and antioxidants of the Asada-Halliwell pathway (Chen et al., 1997; Sairam and Srivastava, 2002). In this pathway, the superoxide radical suffers dismutation by SOD into $\mathrm{H}_{2} \mathrm{O}_{2}$ which in turn is scavenged by CAT and various peroxidases. Both APX and GR also play a key role by reducing $\mathrm{H}_{2} \mathrm{O}_{2}$ to water through the ascorbate-glutathione cycle (Noctor and Foyer, 1998). 28Homobrassinolide may confer tolerance to salt stress by increasing the activities of antioxidative enzymes and/or by reducing the uptake of salts as indicated by previous studies where HBL reduced the uptake of heavy metals and activated the antioxidative enzymes of Oryza sativa, Brassica juncea and Zea mays plants (Özdemir et al., 2004; Bhardwaj et al., 2007; Sharma and Bhardwaj, 2007; Arora et al., 2008). In addition, Zhang et al. (2007) observed that brassinoloide treatment of Medicago sativa increased the germination percentage, fresh weight and activities of antioxidative enzymes (POD, SOD and CAT).

Brassinosteroids are found to affect the transcription and translation processes of specific genes related to stress-tolerance (Kagale et al., 2007). As membrane destruction results from ROS-induced oxidative damage, which ultimately increases the MDA content, the HBL treatments may be involved in scavenging ROS more effectively in the plants. Our observations are in agreement with the results of Özdemir et al. (2004), who

Table 1. Effect of HBL on protein and malondialdehyde (MDA) concentrations, and specific activities of antioxidative enzymes [superoxide dismutase (SOD), guaiacol peroxidase (POD), catalase (CAT), ascorbate peroxidase (APX) and glutathione reductase (GR)] of 30-d-old maize plants. $n=3 \pm$ SE. Asterisks indicate significance at $P \leq 0.05$ [Inside bracket is HSD (Honestly Significant Differences) value].

\begin{tabular}{|c|c|c|c|c|c|c|c|}
\hline $\begin{array}{l}\text { Treatments of } \\
\text { HBL }\end{array}$ & $\begin{array}{l}\text { Protein }\left(\mathrm{g} \mathrm{kg}^{-1}\right. \\
\text { FW) }\end{array}$ & $\begin{array}{l}\text { MDA(mmol } \\
\left.\mathrm{kg}^{-1} \mathrm{FW}\right)\end{array}$ & $\begin{array}{l}\text { SOD }\left(\mathrm{U} \min ^{-1}\right. \\
\left.\text { mg }^{-1} \text { protein }\right)\end{array}$ & $\begin{array}{l}\text { POD (mmol } \\
\text { GDHP } \text { min }^{-1} \\
\left.\mathrm{mg}^{-1}\right)\end{array}$ & $\begin{array}{l}\text { CAT (mol } \\
\mathrm{H}_{2} \mathrm{O}_{2} \mathrm{~min}^{-1} \\
\left.\mathrm{mg}^{-1}\right)\end{array}$ & $\begin{array}{l}\text { APX (mmol } \\
\text { ascorbate } \text { min }^{-1} \\
\left.\mathrm{mg}^{-1}\right)\end{array}$ & $\begin{array}{l}\text { GR(mmol } \\
\text { NADPH min } \\
\mathrm{mg}^{-1} \text { ) }\end{array}$ \\
\hline$\overline{0}$ & $28.38 \pm 1.86$ & $6.06 \pm 0.16$ & $9.02 \pm 0.85$ & $8.79 \pm 0.22$ & $4.06 \pm 0.09$ & $5.67 \pm 0.23$ & $1.75 \pm 0.16$ \\
\hline $10^{-8} \mathrm{mM}$ & $32.04 \pm 0.87$ & $5.50 \pm 0.23$ & $10.37 \pm 0.54$ & $9.83 \pm 0.27$ & $5.71 \pm 0.60$ & $8.45 \pm 0.49$ & $2.07 \pm 0.13$ \\
\hline $10^{-6} \mathrm{mM}$ & $33.54 \pm 0.54$ & $4.67 \pm 0.20$ & $12.93 \pm 0.54$ & $9.99 \pm 0.46$ & $6.32 \pm 0.46$ & $8.90 \pm 0.15$ & $2.50 \pm 0.08$ \\
\hline $10^{-4} \mathrm{mM}$ & $33.33 \pm 0.75$ & $5.87 \pm 0.19$ & $10.59 \pm 0.51$ & $9.61 \pm 0.22$ & $5.68 \pm 0.49$ & $8.45 \pm 0.32$ & $2.44 \pm 0.22$ \\
\hline F-ratio & $4.46(5.11)^{*}$ & $9.50(0.90)^{*}$ & $12.84(2.15)^{*}$ & $2.92(1.41)$ & $4.48(2.07)^{*}$ & $20.60(1.47)^{*}$ & $4.8(0.72)^{*}$ \\
\hline
\end{tabular}


Table 2. Effect of HBL on protein and malondialdehyde (MDA) concentrations, and specific activities of antioxidative enzymes [superoxide dismutase (SOD), guaiacol peroxidase (POD), catalase (CAT), ascorbate peroxidase (APX) and glutathione reductase (GR)] of 30-d old salt-stressed maize plants. Statistics as in Table 1.

\begin{tabular}{|c|c|c|c|c|c|c|c|}
\hline Treatments & $\begin{array}{l}\text { Protein }\left(\mathrm{g} \mathrm{kg}^{-1}\right. \\
\text { FW) }\end{array}$ & $\begin{array}{l}\text { MDA(mmol } \\
\left.\mathrm{kg}^{-1} \mathrm{FW}\right)\end{array}$ & $\begin{array}{l}\text { SOD }\left(U \min ^{-1}\right. \\
\left.\mathrm{mg}^{-1}\right)\end{array}$ & $\begin{array}{l}\text { POD (mmol } \\
\text { GDHP } \text { min }^{-1} \\
\left.\mathrm{mg}^{-1}\right)\end{array}$ & $\begin{array}{l}\text { CAT (mol } \\
\mathrm{H}_{2} \mathrm{O}_{2} \text { min }^{-1} \\
\left.\mathrm{mg}^{-1}\right)\end{array}$ & $\begin{array}{c}\text { APX }(\mathrm{mmol} \\
\text { ascorbate } \\
\left.\mathrm{min}^{-1} \mathrm{mg}^{-1}\right)\end{array}$ & $\begin{array}{l}\text { GR(mmol } \\
\text { NADPH } \text { min }^{-1} \\
\left.\mathrm{mg}^{-1}\right)\end{array}$ \\
\hline$\overline{\mathrm{NaCl}}(25 \mathrm{mM})$ & $27.30 \pm 1.24$ & $6.54 \pm 0.13$ & $11.01 \pm 0.26$ & $8.96 \pm 0.58$ & $5.24 \pm 0.33$ & $7.85 \pm 0.35$ & $1.99 \pm 0.06$ \\
\hline $\begin{array}{l}\mathrm{NaCl}(25 \mathrm{mM})+ \\
\mathrm{HBL}\left(10^{-8} \mathrm{mM}\right)\end{array}$ & $28.64 \pm 1.35$ & $5.91 \pm 0.16$ & $17.47 \pm 1.22$ & $13.99 \pm 0.26$ & $9.17 \pm 0.85$ & $10.41 \pm 0.40$ & $2.18 \pm 0.05$ \\
\hline $\begin{array}{l}\mathrm{NaCl}(25 \mathrm{mM})+ \\
\mathrm{HBL}\left(10^{-6} \mathrm{mM}\right)\end{array}$ & $30.78 \pm 2.59$ & $5.23 \pm 0.22$ & $11.73 \pm 0.71$ & $8.99 \pm 0.74$ & $6.25 \pm 0.85$ & $7.93 \pm 0.72$ & $2.31 \pm 0.10$ \\
\hline $\begin{array}{l}\mathrm{NaCl}(25 \mathrm{mM})+ \\
\mathrm{HBL}\left(10^{-4} \mathrm{mM}\right)\end{array}$ & $28.00 \pm 1.83$ & $6.33 \pm 0.42$ & $16.47 \pm 1.14$ & $13.60 \pm 1.65$ & $8.05 \pm 0.06$ & $12.10 \pm 0.43$ & $2.03 \pm 0.07$ \\
\hline F-ratio & $0.67(8.30)$ & $4.96(1.17)^{*}$ & $12.67(4.16)^{*}$ & $8.52(4.35)^{*}$ & $8.08(2.81)^{*}$ & $16.96(2.26)^{*}$ & $4.31(0.32)^{*}$ \\
\hline$\overline{\mathrm{NaCl}}(50 \mathrm{mM})$ & $21.38 \pm 1.39$ & $6.74 \pm 0.16$ & $12.03 \pm 1.48$ & $11.96 \pm 1.43$ & $8.82 \pm 0.64$ & $9.82 \pm 0.38$ & 2.170 .13 \\
\hline $\begin{array}{l}\mathrm{NaCl}(50 \mathrm{mM})+ \\
\mathrm{HBL}\left(10^{-8} \mathrm{mM}\right)\end{array}$ & $24.09 \pm 1.18$ & $5.44 \pm 0.49$ & $14.76 \pm 0.25$ & $10.77 \pm 0.49$ & $11.3 \pm 0.57$ & $13.95 \pm 1.15$ & $2.46 \pm 0.2$ \\
\hline $\begin{array}{l}\operatorname{NaCl}(50 \mathrm{mM})+ \\
\mathrm{HBL}\left(10^{-6} \mathrm{mM}\right)\end{array}$ & $30.38 \pm 1.15$ & $4.66 \pm 0.30$ & $12.24 \pm 0.22$ & $13.28 \pm 0.49$ & $10.66 \pm 0.27$ & $10.04 \pm 0.52$ & $2.91 \pm 0.50$ \\
\hline $\begin{array}{l}\mathrm{NaCl}(50 \mathrm{mM})+ \\
\mathrm{HBL}\left(10^{-4} \mathrm{mM}\right)\end{array}$ & $22.77 \pm 0.67$ & $6.38 \pm 0.37$ & $16.19 \pm 1.10$ & $11.95 \pm 0.23$ & $9.39 \pm 0.57$ & $10.57 \pm 0.51$ & $3.71 \pm 0.27$ \\
\hline F-ratio & $12.31(5.12)^{*}$ & $6.97(1.61)^{*}$ & $4.61(4.25)^{*}$ & $1.60(3.66)$ & $4.51(2.42)^{*}$ & $7.38(3.21)^{*}$ & $4.61(1.41)^{*}$ \\
\hline $\mathrm{NaCl}(75 \mathrm{mM})$ & $20.5 \pm 0.81$ & $8.08 \pm 0.58$ & $13.37 \pm 0.84$ & $12.27 \pm 0.35$ & $9.13 \pm 0.54$ & $10.24 \pm 0.42$ & $3.48 \pm 0.50$ \\
\hline $\begin{array}{l}\mathrm{NaCl}(75 \mathrm{mM})+ \\
\mathrm{HBL}\left(10^{-8} \mathrm{mM}\right)\end{array}$ & $28.04 \pm 1.72$ & $6.98 \pm 0.33$ & $13.82 \pm 0.57$ & $13.44 \pm 0.56$ & $11.00 \pm 1.08$ & $10.87 \pm 0.48$ & $3.65 \pm 0.13$ \\
\hline $\begin{array}{l}\mathrm{NaCl}(75 \mathrm{mM})+ \\
\mathrm{HBL}\left(10^{-6} \mathrm{mM}\right)\end{array}$ & $25.39 \pm 2.25$ & $7.49 \pm 0.32$ & $14.73 \pm 0.62$ & $12.49 \pm 0.42$ & $9.31 \pm 1.47$ & $10.86 \pm 0.67$ & $3.52+0.33$ \\
\hline $\begin{array}{l}\mathrm{NaCl}(75 \mathrm{mM})+ \\
\mathrm{HBL}\left(10^{-4} \mathrm{mM}\right)\end{array}$ & $24.48 \pm 0.41$ & $6.40 \pm 0.28$ & $13.45 \pm 1.42$ & $12.35 \pm 1.81$ & $9.15 \pm 0.49$ & $11.49 \pm 0.52$ & $3.57 \pm 0.37$ \\
\hline F-ratio & $4.37(6.76)^{*}$ & $3.25(1.79)$ & $0.45(4.20)$ & $0.30(4.48)^{*}$ & $0.84(4.45)$ & $0.91(2.41)$ & $0.04(1.16)$ \\
\hline
\end{tabular}

found that lipid peroxidation induced by $\mathrm{NaCl}$ was significantly lowered in EBL-treated rice seedlings.

Summing up, the pre-sowing treatment of HBL enhanced the tolerance of maize plants to oxidative stress generated by $\mathrm{NaCl}$ by enhancing the activities of antioxidative enzymes. The higher activity of these enzymes suggests a possible role of HBL in amelioration of oxidative stress generated by salt stress and in boosting the resistance capacity of the plants.

Acknowledgement: Financial assistance from the University Grants Commission, New Delhi, India is duly acknowledged.

\section{REFERENCES}

Aebi H (1974) Catalase. In: Bergmeyer HU (ed), Methods of Enzymatic Analysis, pp.673-584.Verlag Chemie, Weinhan.

Arora A, Sairam RK, Srivastava GC (2002) Oxidative stress and antioxidative system in plants. Curr. Sci. 82:1227-1238.

Arora N, Bhardwaj R, Sharma P, Arora HK (2008) Effects of 28-homobrassinolide on growth, lipid peroxidation and antioxidative enzyme activities in seedlings of Zea mays L. under salinity stress Acta Physiol. Plant. doi10.1007/s11738-008-0188-9. 
Asada K, Takahashi M (1987) Production and scavenging of active oxygen in photosynthesis. In: Kyle DJ, Osmond CJ, Artzen CJ (eds), Photoinhibition: Topics in Photosynthesis, pp.227-287. Elsevier, Amsterdam.

Bailey NTJ (1995) Statistical Methods in Biology ( $3^{\text {rd }}$ edition). The English University Press, London.

Bajguz A, Tretyn A (2003) The chemical characteristic and distribution of brassinosteroids in plants. Phytochemistry 62:1027-1046.

Bhardwaj R, Arora N, Sharma P, Arora HK (2007) Effects of 28-homobrassinolide on seedling growth, lipid peroxidation and antioxidative enzyme activities under nickel stress in seedlings of Zea mays L. Asian J. Plant Sci. 6:765-772.

Cao S, Xu Q, Cao Y, Qian K, An K, Zhu Y, Binzeng H, Zhao H, Kuai B (2005) Loss-of- function mutation in DET2 gene lead to an enhanced resistance to oxidative stress in Arabidopsis. Physiol. Plant. 123:57-66.

Carlberg I, Mannervik B (1975) Purification of the flavoenzyme glutathione reductase from rat liver. J. Biol. Chem. 250:5475-5480.

Chen YW, Shao GH, Chang RZ (1997) The effect of salt stress on superoxide dismutase in various organelles of cotyledons of soybean seedlings. Acta Agron. Sin. 23:214-219.

Heath RL, Packer L (1968) Photoperoxidation in isolated chloroplasts. I. Kinetics and stiochiometry of fatty acid peroxidation. Arch. Biochem. Biophys. 125:189-198.

Kagale S, Divi UK, Krochko JE, Keller WA, Krishna P (2007) Brassinosteroids confers tolerance in Arabidopsis thaliana and Brassica napus to a range of abiotic stresses. Planta 225:353-364.

Kono Y (1978) Generation of superoxide radical during autooxidation of hydroxylamine and an assay for superoxide dismutase. Arch. Biochem. Biophys. 186:189-195.
Lowry OH, Rosenbrough NJ, Farr AL, Randall RJ (1951) Protein measurement with folin- phenol reagent. J. Biol. Chem. 193:265-275.

Nakano Y, Asada K (1981) Hydrogen peroxide is scavenged by ascorbate specific - peroxidase in spinach chloroplasts. Plant Cell Physiol. 22:867-880.

Noctor G, Foyer CH (1998) Ascorbate and glutathione: keeping active oxygen under control. Annu. Rev. Plant Physiol. Plant Mol. Biol. 49:249-279.

Nunez M, Mazzafera P, Mazorra LM, Siqueira WJ, Zullo MAT (2003) Influence of brassinosteroid analogue on antioxidant enzymes in rice grown in culture medium with NaCl. Biol. Plant. 47:67-70.

Özdemir F, Bor M, Demiral T, Turkan I (2004) Effects of 24epibrassinolide on seed germination, seedling growth, lipid peroxidation, proline content and antioxidative system of rice (Oryza sativa L.) under salinity stress. Plant Growth Regul. 42:203-211.

Putter J (1974) Peroxidase. In: Bergmeyer HU (ed), Methods of Enzymatic Analysis, pp.685-690. Verlag Chemie, Weinhan.

Sairam RK, Srivastava GC (2002) Changes in antioxidant activity in sub-cellular fractions of tolerant and susceptible wheat genotypes in response to long-term salt stress. Plant Sci. 162:897-904.

Sairam RK, Tyagi A (2004) Physiology and molecular biology of salinity stress tolerance in plants. Curr. Sci. 86:407-421.

Sharma P, Bhardwaj R (2007) Effects of 24-Epibrassinolide on growth and metal uptake in Brassica juncea L. under copper metal stress. Acta Physiol. Plant. 29:259-263.

Zhang S, Hu J, Zhang Y, Xie XJ, Knapp A (2007) Seed priming with brassinolide improves lucerne (Medicago sativa L.) seed germination and seedling growth in relation to physiological changes under salinity stress. Aust. J. Agric. Res. 58:811-815. 